\title{
Small business participation in the advanced technology program research alliances
}

\author{
Richard N Spivack
}

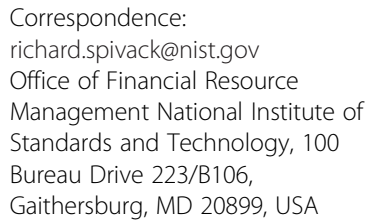

Correspondence:

richard.spivack@nist.gov

Office of Financial Resource

Management National Institute of

Standards and Technology, 100

Bureau Drive 223/B106,

Gaithersburg, MD 20899, USA

\section{焦 Springer}

\begin{abstract}
This study uses a database of small businesses that participated in the US Department of Commerce's Advanced Technology Program (ATP) to observe the role of research alliances in undertaking high-risk technology research and development. The initial hypothesis is that small businesses benefit from membership in research alliances. This study examines two forms of research alliances: single applicants with subcontractor(s) and membership in a joint venture. The basis for the analysis includes data collected during the term of the project. Using data collected at project end provides a limited view of success as commercial achievements may come much later, and small businesses may derive advantages from participating in alliances not captured in the variables used. In light of this, the findings point to successful participation in ATP for small businesses as being dependent upon the type of organizational structure chosen as well as the role played by the small business in the research alliance. For example, assuming the role of the joint venture lead contributed to more successful technical and business outcomes.
\end{abstract}

Keywords: Advanced technology program; Government technology R\&D program; Small business technology R\&D; Technology economic growth

\section{Introduction}

Small businesses play a significant role in technology research and development (R\&D), often being referred to as 'engines of innovation' in scientific research. ${ }^{\text {a }}$ One assumption is that large businesses often are too unwieldy or too risk averse to delve into the area of 'high-risk' technology R\&D that small businesses undertake (Branscomb and Auerswald 2002), but technology R\&D requires a mix of small, medium, and large companies, each offering their unique strengths as well as perspectives (Dyer et al. 2006).

The Advanced Technology Program (ATP) was a federal science and technology program with a mission to accelerate the development of long-term, high-risk technologies leading to broad national benefits through partnerships with the private sector. ${ }^{\mathrm{b}}$ Small companies have played a vital role in this program. Between 1990 and 2004, 508 awards (from a total of 768) were made to small companies as single applicants, single applicants with subcontractor(s), and members of joint ventures. ${ }^{\mathrm{c}}$ ATP tracked the technical achievements, dissemination of technical information, and commercialization of products and services during the project's lifetime and for several years following

(C) 2013 Spivack; licensee Springer. This is an Open Access article distributed under the terms of the Creative Commons Attribution License (http://creativecommons.org/licenses/by/2.0), which permits unrestricted use, distribution, and reproduction in any medium, provided the original work is properly cited. 
project completion. ${ }^{\mathrm{d}}$ The data collected through this program provide a unique opportunity to study the innovation process.

How well small businesses accomplish their technical and commercial goals is often a function of the organizational structure formed to participate in the ATP. Several studies point to the merits of research alliances as enabling 'resource poor' small businesses to gain access to production capacity and a path to the market available from other organizations. A counter argument, deterring small business participation in research alliances, refers to the 'dependency' that occurs when small businesses participate in collaborative arrangements, thus jeopardizing their ability to appropriate most (if not all) of the returns from their investment (Miles 1999).

Using data from the ATP business reporting system (BRS), collected on a routine and regular basis, this paper examines the idea that technological innovation is influenced by organizational characteristics. Small business success in ATP-funded projects is observed across various structures in which a small company was participating in an ATP project. These structures include participation as a single company with no contractors involved (single applicant, SA), as a single company collaborating with subcontractor(s) (single applicant with subcontrator, SAS), as a joint venture leader (JVL) organization, or as a non-lead member of a joint venture (JV member). This analysis does not consider small companies participating only as a subcontractor on a project.

This paper considers the hypothesis that small businesses will be more successful in undertaking technology R\&D, both in terms of technical and commercial success, if they are involved in increasing collaborative efforts. Indicators of success are assessed by applying the composite performance rating system (CPRS) approach developed for ATP to measure firm success. (The CPRS, developed by Rosalie Ruegg, is explained in detail in Ruegg 2006). Success indicators are characterized in two categories: (1) knowledge creation and dissemination and (2) commercialization. Examining these variables in relationship to the organizational structure may yield results that have implications for organizational decisions for small businesses when undertaking the types of technology R\&D required of participants in the ATP and possibly for technology R\&D in general. The success of small businesses when universities participate in research alliances is also examined.

\section{Background}

The focus of this paper is on the organizational structure(s) that best contributes to the success of small companies, both technically and commercially, in the ATP. Do research alliances offer small companies a better opportunity to achieve their technical goals? Do research alliances offer small companies a better opportunity to achieve their business goals? Do small companies stand a better chance of achieving these goals if they undertake projects by themselves, collaborate with subcontractors, operate as a member of a joint venture, or assume the role of joint venture lead? Does the presence of a university partner in a research alliance contribute to participant success?

This study begins with a review of the literature regarding the significance of business size in undertaking high-risk technology $R \& D$. The emphasis is on the role of small businesses. This study observes three organizational structures and one management choice that small businesses have adopted when engaged in ATP-funded projects. Each 
arrangement is examined for its contribution to the technical and commercial success of the small businesses.

Working with data from a sample of ATP-funded projects, restricted to those projects with small business participation, success is defined in terms of selected variables encompassing both the technical and commercial goals of the ATP. This study also considers the unique attributes that small businesses bring to research alliances the value that research alliances offer small businesses, the type of management structure most beneficial to small businesses engaged in research alliances, and the contributions of university participation to small businesses.

Econometric analysis is used to gauge the significance of selected variables in determining success as well as observing the direction of impact attributed to organizational and management structure on small business participation in high-risk technology R\&D in the ATP.

This study concludes with a review of previous studies regarding small business participation in the ATP and how research alliances, with and without university participation, affect the technical and commercial achievements of small businesses.

\section{Firm size}

The debate over firm size in technology R\&D offers a number of arguments highlighting the role of small businesses, emphasizing their willingness to assume more technical risk. Small businesses have been credited with contributing to revolutionary technological breakthroughs often shunned by large firms seeking to avoid risk (p. 28 in Baumol 2004). Small businesses have been credited with producing twice as many significant innovations as large businesses (p. 36 in Litvak 1992; p. 20 in Anderson 2004), and small businesses have been recognized for their contributions to technological advancement due to their flexible organizational structures allowing them to achieve greater focus due to their ability to operate with little more than good ideas and a few highly skilled people. Their smallness allows them to avoid the size constraints associated with internal political hurdles and bureaucratic barriers (p. 456 in Miles 1995; p. 5 in Baumol 2004).

Small businesses often face resource constraints that large businesses are able to surmount. Small businesses, by their nature, experience a condition known as 'resource poverty', which distinguishes them from their larger counterparts (p. 34 in Litvak 1992). The ability to overcome these resource constraints points to the importance of large businesses and the role they play in technology R\&D. While small businesses play a significant role in the establishment of new phases of industry, it is often during the latter phases of industrial innovation that large businesses gain in importance as greater resource costs are involved and considerable market power is required if innovation is to prove worthwhile (p. 6 in Rothwell 1983).

Large businesses are therefore capable of undertaking certain types of technology $R \& D$, different from that of small businesses. Small businesses have a relative advantage in industries which are highly innovative, utilize a high ratio of skilled labor to capital, and tend to be composed of a relatively high proportion of large firms. Large businesses, on the other hand, tend to have an innovative advantage in industries which are capital intensive, concentrated, highly unionized, and produce a differentiated good (p. 567 in Acs and Audretsch 1987). Research collaborations offer small businesses an opportunity 
to overcome these constraints and take advantage of economies of scale. When a small company takes on the role of joint venture lead, the responsibility as well as authority that this position brings may enhance its ability to achieve both technical and commercial success. ${ }^{e}$

\section{Research alliances}

A large body of economic, business, and policy literature has pointed towards the benefits from R\&D collaborations as offering a mechanism to correct market failures and increase the rate of technology creation and diffusion in the industry (Caloghirou et al. 2003; Hagedoorn et al. 2000; Vonortas 1997). The basic rationale has rested on traditional market failure arguments emphasizing insufficient incentives for individual firms to undertake risky and imperfectly appropriable research at the socially optimal level. Other arguments have included better access to resources and markets. More specifically, it has been argued that $R \& D$ collaborations may enable industrial participants to share $R \& D$ costs, reduce uncertainty, internalize spillovers, and achieve research synergies.

The literature is rich with reasons why research alliances are beneficial for small businesses:

1) Alliances may be particularly suited to early-stage, technology-based firms experiencing lack of resources.

2) Alliances appear to be an attractive option for allowing small businesses to exploit their complementary resources and to gain access to markets.

3) Alliances are especially popular in risky, uncertain situations enabling firms to spread risk (pp. 20 and 24 in Miles et al. 1999; p. 20 in Anderson 1990).

Many small businesses possess innovative ideas and talent but lack the resources and experience to fully capitalize on them. In this instance, forming a research alliance makes sense as additional resources are made available. In cases where small businesses possess sufficient resources to accomplish their technical as well as commercial goals, they may prefer to remain independent of formal alliances, wary of losing control over the project's objectives as well as concerned about the ability to fully appropriate the fruits of their efforts. While most research alliances enhance the capabilities of small businesses, some evidence has emerged indicating that alliances alone are no guarantee of successful performance and, in some cases, result in even poorer performance. (pp. 20-26 in Miles et al. 1999; Vonortas and March 2005).

ATP-funded research alliances varied in number and composition, including a variety of business sizes (small, medium, and large) as well as for-profit and not-for-profit organizations (universities, federal labs, research centers). Participation could either be in the form of a single applicant or a member of a joint venture. In response to the ATP statute regarding joint ventures, two basic models were developed: alliances encompassing at least two for for-profit companies that may have included additional businesses, universities, federal labs, research centers as co-signatories to the awarded project, as well as subcontractors; and, alliances in which a single for-profit company incorporates one or more subcontractors into their projects (not as co-signatories to the ATP award) (Advanced Technology Program 2005). For purposes of this paper, both of these organizational structures will be 
referred to as research alliances. ${ }^{\mathrm{f}}$ In some cases, involving the first model small businesses assumed the leadership role.

\section{Universities}

Universities play a key role in the US innovation system. They are engaged in scientific and technological research often collaborating with private industry. Universities participating in research alliances frequently do so to complement ongoing research activities, gain access to additional resources, seek additional funding, and enable their faculty, students, and staff to work with eminent researchers. Universities offer a number of resources sought by the private industry sector including technical expertise, access to expensive capital assets, and assistance in acquiring and assimilating basic knowledge for the project's success (p. 23 in Hall et al. 2002).

In a report highlighting the importance of university-industry research collaborations it was noted "...that we are living in a time of truly historic transformation - one rooted in the rise of a knowledge society based largely on the collaborative generation and use of information." The study also noted that "corporations and universities are not natural partners. Their culture and their missions differ. The companies' underlying goals - and the prime responsibilities of top management - are to make profit and build value for shareholders. Universities' traditional missions are to develop new knowledge and educate the next generation" (ACE 2001).

Indeed, many small businesses have a close link to one or more universities from the outset. At the same time, small businesses may experience a degree of apprehension when working with academic partners who may be more concerned about publishing papers than they are about protecting proprietary information. Universities are in the business of publishing the results of their research but doing so before a patent is secured may hamper the ability of a business to receive one. ${ }^{\mathrm{g}}$

\section{The role of the government}

Small technology-based businesses frequently are unable to obtain private sector funding due to a number of factors including the investor's receipt of asymmetric information, the need for a quick return on investment, research resulting in infrastructural or 'tool' development, and the patience needed to withstand long regulatory delays. Traditional lending and financial institutions are typically either unwilling or lack the resources to back small business' high-technology R\&D as they may be several years away from providing returns on their investments. Often, it is when businesses can demonstrate a proven track record in sales and product development, possess a prototype, or are close to commercialization that venture capitalists, and other investors will risk their funds (p. 35 in Litvak, 1992). (p. 453-454 in Miles and Preece 1995).

The economics literature often refers to the importance of spillovers, or social benefits, emanating from technology R\&D. In other words, the added benefits from undertaking $R \& D$ are in many cases not captured by the investor. Spillovers result in additional value to society being derived from the research. Government participation may be necessary to ensure a level of investment that is justified in terms of the level of societal returns. In this study, spillovers are observed through knowledge creation and knowledge dissemination variables (publications, conferences, and patents). 
"Economists and other social scientists have demonstrated that the R\&D activities of private firms generate widespread benefits enjoyed by consumers and society at large. As a result, the overall economic value to society often exceeds the economic benefits enjoyed by innovating firms as a result of their research efforts. This excess of the social rate of return over the private rate of return enjoyed by innovating firms is described by economists as a positive externality or spillover. These spillovers imply that private firms will invest less than is socially desirable in research, with the result that some desirable research projects will not be undertaken, and others will be undertaken more slowly, later, or on a smaller scale than would be socially desirable" (p. 1 in Jaffe 1996).

Public-private partnerships, such as ATP, addressed these market failures by providing funding for (1) high-risk, early-stage technologies where private capital is known to be generally not available and (2) projects with very strong potential for national benefits far in excess of company profits.

Government funding plays a particularly important role in new, small business hightechnology firms, which usually have limited profits and capital to support their research. Without government funding during the initial years, many small high technology companies could never develop and commercialize their technology which may eventually contribute to the growth of the economy (p. 23 in Litvak 1992).

Because spillovers play such a critical role in technology R\&D several means of measuring these contributions have been created. It is not surprising that a public-private partnership like ATP included indicators of spillovers among its measures of success. One instrument for assessing progress of projects funded by the ATP toward meeting ATP's multiple goals was the composite performance rating system (CPRS). Developed as an evaluation tool, the CPRS uses uniformly collected output and outcome data (indicator metrics) to compute an overall performance rating for each of ATP's completed projects approximately 4 years after project end (Ruegg 2006). The CPRS attaches weights to indicators and uses a formula to convert to a 'Star System'h which signals project success in terms of ATP program goals. The indicators reflect a firm's ability to create and disseminate the knowledge from technologies resulting from their awarded projects as well as achieve commercial acceptance.

\section{Data source and sample}

The ATP BRS offers a rich source of data for the selected participants. The BRS is a survey instrument that provided information to ATP staff and researchers for project management, evaluation research, and statistical analysis. The BRS consisted of an annual survey of project participants during the course of the project (and subsequent surveys after the end of the project) (Powell 1996). Variables selected for this study reflecting the concepts of knowledge creation and dissemination include the following: patents filed, patents granted, publications, and presentations at conferences. Those variables which capture the concept of commercialization include whether commercial activities were pursued by the awardee or by another company, the receipt of new revenues from the technology, the existence of a prototype or a pilot project, and the receipt of additional funding.

The sample for this paper comes from the BRS and includes 72 small businesses that participated in the ATP as single applicants, 207 small businesses that participated as 
single applicants with subcontractors, and 163 small businesses that participated in joint ventures. Data collected from the close-out reports of each project are used. Members of research alliances are classified as belonging to one of the following alliance types: SAS or joint venture (JV). JVL are listed but not counted in the total. Single applicants with no subcontractors are also included. Table 1 shows the number of sample companies in each alliance type by award year. Only signatories to the ATP award are included in this study. ${ }^{\mathrm{i}}$

Table 2 shows the distribution of companies by technology area for all small businesses included in this sample. Biotechnology companies had the highest representation with $26 \%$, while advanced materials/chemistry companies had the lowest representation (13\%).

Table 3 shows the number of small companies by organizational structure: single applicant, single applicant with a subcontractor(s), and joint venture membership. The table also shows the percentages of participation by alliance type and technical category. The IT and biotechnology areas had the highest incidence of single applicants: $24 \%$ and $21 \%$, respectively, while the manufacturing industry had the lowest, $6 \%$. In terms of the overall study, membership as single applicants with subcontractor(s) exceeded that of joint ventures by $48 \%$ to $36 \%$. Included is the number of JVL showing biotechnology and electronics with the largest numbers.

Table 4 shows the percent of university participation with small companies by technology area. Overall participation is $68 \%$, with manufacturing demonstrating the highest participation at $83 \%$, and electronics the lowest at $52 \%$.

Small businesses in mature industries with significant capital research requirements, such as advanced materials/chemistry and manufacturing, tend to partner with universities to conduct much of their research. These industries require a great deal of expensive resources available primarily at universities; therefore, small businesses in this area are more likely to have university partners who play a significant role in their R\&D activities. The advanced materials/chemistry and manufacturing projects in this study had university participation of $68 \%$ and $83 \%$, respectively.

Table 1 Number of small companies by award year, 1993 to 2004

\begin{tabular}{lccccc}
\hline $\begin{array}{l}\text { Award year } \\
\text { (1993 to 2003) }\end{array}$ & $\begin{array}{c}\text { Single applicants with } \\
\text { no subcontractors (SA) }\end{array}$ & $\begin{array}{c}\text { Single applicant with a } \\
\text { subcontractor(s) (SAS) }\end{array}$ & $\begin{array}{c}\text { Joint venture } \\
\text { member (JV) }\end{array}$ & $\begin{array}{c}\text { Joint venture } \\
\text { lead (JVL) }\end{array}$ & Total \\
\hline 1993 & 0 & 11 & 10 & 2 & 21 \\
1994 & 2 & 19 & 25 & 12 & 46 \\
1995 & 7 & 17 & 55 & 5 & 79 \\
1996 & 1 & 4 & 0 & 0 & 5 \\
1997 & 7 & 25 & 16 & 7 & 48 \\
1998 & 10 & 26 & 23 & 7 & 59 \\
1999 & 3 & 13 & 8 & 4 & 24 \\
2000 & 13 & 19 & 15 & 2 & 47 \\
2001 & 10 & 44 & 5 & 2 & 59 \\
2002 & 6 & 14 & 2 & 0 & 22 \\
2003 & 3 & 2 & 0 & 0 & 5 \\
2004 & 10 & 13 & 4 & 2 & 27 \\
TOTAL & 72 & 207 & 163 & 43 & 442 \\
\hline
\end{tabular}


Table 2 Distribution of small companies by technology area

\begin{tabular}{lcc}
\hline Small-company participant/technology area & Number & Percent (\%) \\
\hline Advanced materials/chemistry & 57 & 13 \\
Biotechnology & 117 & 26 \\
Electronics/Photonics & 96 & 22 \\
Information technology (IT) & 90 & 20 \\
Manufacturing & 82 & 19 \\
Total & 442 & 100 \\
\hline
\end{tabular}

\section{Participant success indicators}

Working from a concept similar to that created for the CPRS, variables are organized along the following lines:

- Knowledge creation and dissemination (measured by patents filed, patents granted, publications, and presentations at conferences).

- Commercialization (measured whether commercialization was being pursued by the company, whether commercialization was being pursued by others, new revenues earned from the technology, the existence of a prototype, whether a pilot product/process exists, and whether there was receipt of additional external funding).

Indicators used in this paper are primarily binary (yes/no). They are constructed from BRS data reported at the end of the project. The data are collected at the company level and record a variable as a 'success' when the company reported either technological accomplishments and/or the existence of commercial activity.

Table 5 shows the percentage of participants who recorded knowledge creation and dissemination success indicators. During the ATP project, $31 \%$ of small company participants had filed patents, $21 \%$ had been granted patents, $35 \%$ had a publication based on the project, and 55\% made a conference presentation about the funded project.

Table 6 shows the percentage of small-company participants who reported commercial success. In general, $88 \%$ reported commercialization of the technology was being planned or pursued by them, 34\% reported commercialization of the technology was being planned or pursued by others, 30\% reported earning new revenues from products/

Table 3 Number of small companies by organizational structure

\begin{tabular}{|c|c|c|c|c|c|c|c|}
\hline $\begin{array}{l}\text { Small-company } \\
\text { participant/ } \\
\text { technology area }\end{array}$ & $\begin{array}{c}\text { Number } \\
\text { of SA }\end{array}$ & $\begin{array}{l}\text { Percentage of } \\
\text { technology } \\
\text { area (\%) }\end{array}$ & $\begin{array}{c}\text { Number } \\
\text { of SAS }\end{array}$ & $\begin{array}{c}\text { Percentage of } \\
\text { technology } \\
\text { area (\%) }\end{array}$ & $\begin{array}{c}\text { Number } \\
\text { of JV } \\
\text { members }\end{array}$ & $\begin{array}{c}\text { Percentage of } \\
\text { technology area } \\
\text { members (\%) }\end{array}$ & $\begin{array}{c}\text { Number } \\
\text { of JVL }\end{array}$ \\
\hline $\begin{array}{l}\text { Advanced } \\
\text { materials/ } \\
\text { chemistry }\end{array}$ & 8 & 14 & 23 & 40 & 26 & 46 & 8 \\
\hline Biotechnology & 24 & 21 & 75 & 64 & 18 & 15 & 11 \\
\hline Electronics & 14 & 14 & 37 & 39 & 45 & 47 & 14 \\
\hline IT & 22 & 24 & 45 & 50 & 23 & 26 & 4 \\
\hline Manufacturing & 5 & 6 & 31 & 38 & 46 & 56 & 6 \\
\hline $\begin{array}{l}\text { Total number of } \\
\text { participants/ } \\
\text { percentage of total }\end{array}$ & 73 & 16 & 211 & 48 & 158 & 36 & \\
\hline
\end{tabular}


Table 4 University participation in research alliances

\begin{tabular}{lcc}
\hline Small-company participant/technology area & $\begin{array}{c}\text { Number of companies interacting } \\
\text { with a university partner }\end{array}$ & Percent (\%) \\
\hline Advanced materials/chemistry & 39 & 68 \\
Biotechnology & 73 & 62 \\
Electronics & 50 & 52 \\
IT & 52 & 58 \\
Manufacturing & 56 & 83 \\
Total & $270^{\text {a }}$ & $68^{\text {b }}$ \\
\hline
\end{tabular}

${ }^{a}$ A university may collaborate with several companies in a research alliance.

${ }^{\mathrm{b}}$ This number represents the percentage of university participation in the 370 research alliances.

processes related to the technology, 33\% reported the production of a prototype, 33\% reported setting up a pilot production/commercial demo, and 56\% reported having received additional funding to develop the technology after the ATP award was announced. "Attraction of additional capital is generally taken as a signal that the level of risk has been sufficiently reduced that others are willing to invest to take the technology into use" (p.40 in Ruegg 2006).

\section{Logistic regressions - knowledge creation and knowledge dissemination}

Knowledge creation and knowledge dissemination lie at the heart of technology R\&D and were key components of each ATP-funded project. The significance of these variables has been recognized in a recent study, to wit "Our analyses strongly implicate publication as an important mechanism for accelerating the rate of technological innovation." (p. 1615 in Sorenson and Fleming 2004). Each proposed project had to provide convincing evidence to ATP selection officials that it has 'strong potential for advancing the state of the art and contributing significantly to the US scientific and technical knowledge base' (Advanced Technology Program 2005). ATP required that the technology be highly innovative and the research challenging. It was assumed that the dissemination of knowledge during and after the project would fuel subsequent developments and lead to national economic (social) benefits.

Logistic regressions ${ }^{j}$ are estimated for each of the company-level output measures: (1) patents filed, (2) patents granted by the participants for innovations flowing out of

Table 5 Percentage of small-company participants with knowledge creation and knowledge dissemination success indicators

\begin{tabular}{|c|c|c|c|c|c|}
\hline $\begin{array}{l}\text { Small-company } \\
\text { participants/ } \\
\text { technology area }\end{array}$ & Number $(n)$ & $\begin{array}{l}\text { Patents filed } \\
(\%)\end{array}$ & $\begin{array}{l}\text { Patents granted } \\
\text { (\%) }\end{array}$ & $\begin{array}{l}\text { Publications } \\
\text { (\%) }\end{array}$ & $\begin{array}{c}\text { Conference } \\
\text { presentations } \\
(\%)\end{array}$ \\
\hline All & 442 & 31 & 20 & 35 & 55 \\
\hline Advanced materials/chemistry (A) & 57 & 37 & 32 & 33 & 56 \\
\hline Biotechnology (B) & 117 & 44 & 33 & 45 & 66 \\
\hline Electronics/Photonics (E) & 96 & 31 & 18 & 31 & 60 \\
\hline Information Technology (I) & 90 & 22 & 10 & 32 & 53 \\
\hline Manufacturing (M) & 82 & 17 & 11 & 26 & 43 \\
\hline
\end{tabular}


Table 6 Percentage of small-company participants with commercialization success indicators

\begin{tabular}{|c|c|c|c|c|c|c|c|}
\hline $\begin{array}{l}\text { Small-company participants/ } \\
\text { technology area }\end{array}$ & Number $(n)$ & $\begin{array}{l}\text { Pursued by the } \\
\text { company }(\%)\end{array}$ & Pursued by others (\%) & New revenues (\%) & $\begin{array}{l}\text { Receipt of additional } \\
\text { funding (\%) }\end{array}$ & $\begin{array}{l}\text { Prototype } \\
\text { exists (\%) }\end{array}$ & $\begin{array}{l}\text { Pilot project } \\
\text { has begun (\%) }\end{array}$ \\
\hline$\overline{\text { All }}$ & 442 & 88 & 34 & 30 & 56 & 33 & 35 \\
\hline Advanced materials/chemistry (A) & 57 & 81 & 33 & 30 & 47 & 40 & 32 \\
\hline Biotechnology (B) & 117 & 95 & 37 & 24 & 68 & 32 & 23 \\
\hline Electronics/Photonics (E) & 96 & 94 & 28 & 27 & 60 & 34 & 24 \\
\hline Information technology (I) & 90 & 96 & 38 & 41 & 52 & 38 & 41 \\
\hline Manufacturing (M) & 82 & 78 & 35 & 23 & 41 & 21 & 16 \\
\hline
\end{tabular}


the project (3) publications in scientific and technical journals, and (4) presentations at scientific and technical conferences reporting research findings. The following variables are included as explanatory variables:

Adv. Mat/Chem, Bio - binary variables indicating that the project is in the technology Elec, IT, Man area - advanced materials/chemistry, biotechnology, electronics, information technology, manufacturing ${ }^{\mathrm{k}}$

Univ - binary variable indicating that the project includes a university as a subcontractor or partner

SA - binary variable indicating that the company is a single applicant, not part of a research alliance

SAS - binary variable indicating that the company is a single applicant with a subcontractor

JV Member - binary variable indicating that the company is a member of a joint venture JV Lead - binary variable indicating that the company is the lead in the joint venture

The following models were examined:

- Patents filed $=\mathrm{f}(\mathrm{C}$, University, Advanced Mat/Chem, Bio, Elec, IT, Single Applicant with Sub, JV member, JV Lead)

- Patents granted $=f(C$, University, Advanced Mat/Chem, Bio, Elec, IT, Single Applicant with Sub, JV member, JV Lead)

- Dissemination publications $=\mathrm{f}(\mathrm{C}$, University, Advanced Mat/Chem, Bio, Elec, IT, Single Applicant with sub, JV member, JV Lead)

- Dissemination conference $=\mathrm{f}(\mathrm{C}$, University, Advanced Mat/Chem, Bio, Elec, IT, Single Applicant with Sub, JV member, JV Lead)

\section{Regression results}

Table 7 presents results from the logistic models identified above. We note that the presence of a university partner demonstrates a negative relationship for both patents granted and patents filed but is not statistically significant for any of the variables observed. In the case of advanced materials/chemistry and biotechnology, estimates of the

Table 7 Knowledge creation/knowledge dissemination

\begin{tabular}{lllll}
\hline Independent variable & \multicolumn{4}{c}{ Dependent variable } \\
\cline { 2 - 5 } & Patents granted & Patents filed & Publications & Conferences \\
\hline University & $-0.5052(0.2827)$ & $-0.1155(0.2561)$ & $0.3613(0.2625)$ & $0.4097(0.2539)$ \\
Adv. materials/chemistry & $1.2549(0.4705)^{\mathrm{a}}$ & $0.8995(0.4181)^{\mathrm{a}}$ & $0.1638(0.3972)$ & $0.4156(0.3754)$ \\
Biotechnology & $1.0950(0.4260)^{\mathrm{a}}$ & $0.8811(0.3710)^{\mathrm{a}}$ & $0.5063(0.3356)$ & $0.3746(0.3251)$ \\
Electronics & $0.4677(0.4547)$ & $0.5634(0.3917)$ & $0.2916(0.3487)$ & $0.3161(0.3277)$ \\
IT & $-0.2327(0.5143)$ & $0.1223(0.4132)$ & $0.2431(0.3549)$ & $-0.0021(0.3348)$ \\
Single applicant/subcontractor & $0.6272(0.3826)$ & $0.0828(0.3519)$ & $-0.0157(0.3459)$ & $-0.3985(0.3420)$ \\
JV member & $-0.4371(0.4972)$ & $-1.2530(0.4618)^{\mathrm{a}}$ & $-1.0128(0.4228)^{\mathrm{a}}$ & $-1.7792(0.4039)^{\mathrm{a}}$ \\
JV lead & $1.7124(0.4523)^{\mathrm{b}}$ & $0.7471(0.4287)^{\mathrm{c}}$ & $0.0005(0.4275)$ & $-0.2891(0.4298)$ \\
\hline
\end{tabular}

$N=442$ standard error shown in parenthesis; ${ }^{a}$ denotes significance at the .01 level; $^{b}$ denotes significance at the .05 level; ${ }^{c}$ denotes significance at the .10 level; All variables are binary (yes/no). 
variable patents granted and patents filed are statistically significant $(0.01,0.01)$ and positive for both, emphasizing the importance of patenting to these industries. The mixed signs and lack of statistical significance for IT and patents is not surprising because IT firms may be expected to rely more on copyrighting (of software) rather than on patenting (Man and SA are the omitted variables).

For small businesses participating as a member of a joint venture, all four estimates of the independent variables are negative, and three are statistically significant $(0.01$, $0.01,0.01$ ). These results may point to the negative impacts that joint ventures pose for their small business participants or it may allude to the limited role that small businesses play in issues related to knowledge creation and knowledge dissemination.

The benefits of alliance membership for small businesses change for those firms that assume a leadership role. In the case where a small business assumes the lead in a joint venture, three of the four knowledge variables are positive. The positive signs and the level of statistical significance $(0.01,0.05)$ for both patents granted and patents filed reinforce the importance of intellectual property issues to a small business. This is not the case, though, where there is a single applicant operating with subcontractor(s); in this situation, the estimates for the knowledge variables are mixed and statistically insignificant.

The positive sign and statistically significant estimates of the leadership variables above may be partially attributed to Audretsch's hypothesis (p. 274 in Audretsch and Feldman 2003), "....three factors shape the formation of alliances - capabilities, control, and context. Capabilities refer to the set of tangible and intangible assets making it feasible for a firm to develop and produce and sell goods and services. Control refers to the authority of the firm to deploy those capabilities. The context refers to the external environment within which the firm operates." A company's ability to acquire and profit from all three conditions may be enhanced if the company assumes the leadership role in the joint venture.

\section{Patents}

Patents are essential to many businesses for a number of reasons, especially for those industries where the 'composition of matter' best defines the research and where knowledge creation/dissemination is often the outcome of research. Patents are important where scientific discoveries result in new findings, where patenting behavior takes place at a greater rate than in other industries, where businesses face more regulatory hurdles than in other industries, and where the industry is still in its infancy. The advanced materials/chemistry and biotechnology industries offer good examples and are industries where defending patents is often easier than, for example, in electronics and IT. ${ }^{1}$

In those industries where cycle times are short, e.g., IT and electronics, securing a patent may not be considered a necessity. Many electronics projects in the ATP were often of an infrastructural nature making it complicated to secure patents. Where patenting is less important and applying for a patent often takes time and is expensive, trade secrets may be used to explain the mechanism by which companies choose to protect their intellectual property (p. 479 in Hemphill 2004).

In a study by Nicholls-Nixon and Woo, using data from the US pharmaceutical industry participation as a member of a joint venture demonstrated negative and statistically significant results for both knowledge creation variables, patents filed, and patents granted. "Contrary to our expectations, the number of patents was actually lower for firms with higher numbers of JV. Perhaps the negative relationship between patent 
output and joint venture activity is a reflection that JVs are used to tackle inherently more complex and risky technology development tasks. As a result, firms that engage in more joint ventures have lower patent output because of the longer time fames required for these collaborative ventures to bear results, and/or because these type of relationships have a lower probability of success" (p. 664 in Nicholls-Nixon and Woo 2003).

\section{Publications/Conferences}

Negative and statistically significant estimates $(0.05,0.001)$ for the variable publications/ conferences are demonstrated for small business members of joint ventures. Similar results are found for single applicants with subcontractor(s) but are not statistically significant. This is not the case for those small businesses assuming a leadership role in the joint venture. In this instance, the estimates are positive and statistically significant $(0.05,0.001)$.

For those industries where staying ahead of one's competitors is critical to survival, publishing may not be important. Small businesses in these industries are very aware of the importance of maintaining a technological advantage and would prefer to pursue publications/conferences after they have secured a patent.

Where patenting is not prevalent, publications/conferences offer the best means of knowledge dissemination. Unfortunately, measuring knowledge dissemination in these industries is not easily captured in the variables selected. This is not to say that knowledge dissemination does not occur but rather remains private and will often diffuse through interpersonal networks (p. 1616 in Sorenson and Fleming 2004).

Companies in the biotechnology industry, where due to the difficulties of clearing the many hurdles imposed by regulatory agencies, find that intellectual property becomes their only marketable product therefore rendering patents as the sole company output. For this industry, publications/conferences may be delayed until the patent is secured. "Potentially profitable research findings may be kept confidential, remain unpublished, or be significantly delayed in order to secure property rights" (p. 277 in Audretsch and Feldman 2003). It should be noted that for many small businesses, getting a product to market is more important than pursuing journals or conference presentations.

\section{Organizational structure}

Trade secrets as a means of protecting intellectual property have taken on a more crucial role in the past few years. For those industries where this is the case, membership in research alliances may be troublesome and trade secrets may be best kept by single applicants, with or without subcontractors. The electronics industry is a case in point. Subcontractors are frequently engaged in undertaking the 'less' risky aspects of the project and often only provide services as part of their contract. The 'process recipes' that resulted from ATP projects remain closely held secrets by the award recipient. ${ }^{\mathrm{m}}$

In relatively new industries, such as biotechnology, research alliance participation is often not the norm. It frequently takes a period of time before the true value of the product/process under development is fully realized or not, and if a project is successful and a research alliance is in place, issues of intellectual property become a source of contention among the members. Biotechnology has the lowest percent of membership participation in joint ventures and the highest percent of single applicants. For older, more established industries, such as manufacturing, research alliance participation is more common (see Table 3). Manufacturing has the highest proportion of joint venture membership and the lowest percentage of single applicant participation. 


\section{Logistic regressions - commercialization}

It is through commercial activity that new knowledge from projects is most directly translated into economic benefits. Commercialization of the developed technology will enhance the overall potential for broad-based national benefits, the ultimate goal of the ATP. Applicants to ATP were required to provide a path to commercialization in their proposals. (Advanced Technology Program various years).

Logistic regressions ${ }^{\mathrm{n}}$ are estimated for each of the company-level output measures: (1) commercialization was being pursued by the company, (2) commercialization was being pursued by another company, (3) new revenues were earned from the technology, (4) a prototype was developed, (5) a pilot project had begun, and (6) new external funding had been received. Using the same explanatory variables identified earlier, the following models were examined:

- Pursued by the company $=\mathrm{f}(\mathrm{C}$, University, Advanced Mat/Chem, Bio, Elec, IT, Single Applicant with Sub, JV Member, JV Lead)

- Pursued by others $=f(C$, University, Advanced Mat/Chem, Bio, Elec, IT, Single Applicant with Sub, JV Member, JV Lead)

- Produced a pilot $=f(C$, University, Advanced Mat/Chem, Bio, Elec, IT, Single Applicant with Sub, JV Member, JV Lead)

- Produced a prototype $=\mathrm{f}(\mathrm{C}$, University, Advanced Mat/Chem, Bio, Elec, IT, Single Applicant with Sub, JV Member, JV Lead)

- Receipt of additional funding $=\mathrm{f}(\mathrm{C}$, University, Advanced Mat/Chem, Bio, Elec, IT, Single Applicant with Sub, JV Member, JV Lead) (from external sources)

- New revenues $=\mathrm{f}(\mathrm{C}$, University, Advanced Mat/Chem, Bio, Elec, IT, Single Applicant with Sub, JV Member, JV Lead) (from the project)

\section{Regression results}

Table 8 presents results from the logistic models identified above. We note that the presence of a university partner resulted in mixed estimates that were statistically insignificant for all of the commercialization variables. Statistical results from membership in research alliances vary based upon organizational structure. For example, joint venture membership resulted in parameter estimates with mixed signs and estimates that were negative and statistically significant for the variables new revenues generated and receipt of additional funds $(0.05,0.001)$. Joint venture leads had positive and statistically significant estimates for all of the commercialization variables $(0.01,0.05,0.10,0.05$, $0.01,0.001)$. For single applicants with subcontractor(s), estimates of the variable commercialization pursued by the company and commercialization pursued by others were both positive and statistically significant $(0.10)$.

Are the types of research alliances different? Observing the results from Tables 7 and 8, one notices that small business membership in a joint venture results in more statically significant estimates then a single applicant with subcontractor(s). In all cases, the signs are negative.

Assuming the role of lead in a joint venture can be beneficial to a small business' commercialization plans. In this study, estimates of all the commercialization and knowledge variables in the case of the joint venture lead were positive and statistically 
Table 8 Commercialization activities of the new technology

\begin{tabular}{|c|c|c|c|c|c|c|}
\hline $\begin{array}{l}\text { Dependent variable } \\
\text { Independent variable }\end{array}$ & $\begin{array}{l}\text { Commercial. pursued } \\
\text { by the company }\end{array}$ & $\begin{array}{l}\text { Commercial. pursued } \\
\text { by others }\end{array}$ & A pilot project exists & A prototype exists & $\begin{array}{l}\text { New revenues } \\
\text { generated }\end{array}$ & $\begin{array}{l}\text { Receipt of } \\
\text { additional funding }\end{array}$ \\
\hline University & $-9127(0.5220)^{a}$ & $-0.1646(0.2495)$ & $0.0511(0.2776)$ & $-0.0631(0.2575)$ & $-0.0966(0.2768)$ & $-0.5374(0.2667)^{a}$ \\
\hline Adv. materials/chemistry & $-.1359(0.4762)$ & $-0.0314(0.3730)$ & $0.9568(0.4212)^{b}$ & $0.7295(0.3934)$ & $0.0351(0.4086)$ & $-0.0799(0.3885)$ \\
\hline Biotechnology & $0.4813(0.5374)$ & $-0.0148(0.3227)$ & $0.3280(0.3888)$ & $0.3814(0.3488)$ & $0.3591(0.3649)$ & $0.5007(0.3391)$ \\
\hline Electronics & $0.5928(0.4618)$ & $-0.2882(0.3325)$ & $0.5913(0.3905)$ & $0.5590(0.3537)$ & $0.1234(0.3650)$ & $0.5265(0.3428)$ \\
\hline IT & $1.4901(0.6059)^{c}$ & $0.1442(0.3318)$ & $1.3002(0.3821)^{c}$ & $0.5802(0.3604)$ & $0.6302(0.3528)^{a}$ & $-0.0104(0.3488)$ \\
\hline Single applicant/subcontractor & $1.5661(0.7383)^{b}$ & $0.5896(0.3514)$ & $-0.3360(0.3585)$ & $-0.0076(0.3401)$ & $-0.4983(0.3568)$ & $0.1020(0.3704)$ \\
\hline JV member & $-0.5995(0.7084)$ & $0.1890(0.4094)$ & $-0.9067(0.4317)^{b}$ & $-0.7465(0.4103)^{a}$ & $-0.9129(0.4291)^{b}$ & $-1.5497(0.4237)^{c}$ \\
\hline JV lead & $1.3848(0.5717)$ & $0.9295(0.4299)^{b}$ & $-0.0955(0.4473)$ & $0.1210(0.4230)$ & $-0.2719(0.4349)$ & $0.1734(0.4635)$ \\
\hline$N=442$ & & & & & & \\
\hline
\end{tabular}

Standard error shown in parenthesis; ${ }^{\text {a }}$ denotes significance at the 0.10 level; ${ }^{b}$ denotes significance at the 0.05 level; ${ }^{c}$ denotes significance at the 0.01 level; All variables are binary (yes/no). 
significant. This demonstrates the importance of commercialization to the very survival of a small business and may help explain why a small business would be inclined to assume the leadership role in a joint venture.

\section{Commercialization}

Achieving commercial success by the time of the close-out of an ATP project is not something that is necessarily expected or required. While ATP required applicants to submit a plan containing a commercial pathway and identify potential markets, it is also understood that the very nature of the technology R\&D undertaken may not result in commercializable products/processes until several years after project completion, but awardees are expected to pursue commercial avenues as soon as feasible. Prototypes, pilot projects, as well as the receipt of additional funding are considered indicators of progress towards commercialization.

In a study of ATP awardees, it was noted that commercialization patterns differ for projects in different technology areas. Information technologies enter the market quickly while materials and chemistry and manufacturing technologies are anticipated to be the slowest to earn revenues. Biotechnology projects often face long regulatory hurdles before commercialization, while “...71\% of electronics applications are expected to earn revenues within two years after ATP funding ends" (p. 6 in Powell and Morris 2002).

\section{Research alliances and commercialization}

Working within the limitations of the data collected for this study, membership in research alliances did not significantly contribute to commercialization activities. In some instances, membership in a joint venture actually had a negative impact upon the commercialization indicators. It is quite common for members of research alliances to develop and maintain their own business plans and perform one task or one piece of the technology development. The research alliance serves as a convenient means of tackling the technology hurdles faced by the alliance and, upon successful project completion, individual members often pursue commercialization on their own. This can be partially observed in the case of those small businesses serving as the joint venture lead and the positive signs displayed, though in many cases they were statistically insignificant.

Research alliances can prove burdensome once a product/process is ready for the market. The start of sales and the receipt of funds could lead to misunderstandings among the members leading to the dismantling of the alliance. For many small businesses, protection of intellectual property is often their only means of appropriating the fruits of their efforts and is crucial to attracting additional funding thus ensuring their continued survival.

\section{Universities}

Recognizing the importance of university-industry research collaborations, while at the same time being aware of the different goals of the organizations, this study points to the lack of statistical significance for estimates of the variables knowledge creation and knowledge dissemination for small business membership in joint ventures with university partners. In addition, mixed estimates were observed for all of the commercialization variables when small businesses were members in joint ventures with university partners contributing to the further understanding of how universities impact commercial activities. 
Universities are not in the business of commercialization but are in the business of knowledge creation and knowledge dissemination. One possible interpretation of the regression results is that when a small business partners with a university, it does so for the purpose of securing the technical resources that a university has to offer, and the small business itself is not interested in immediately disseminating its results through the usual university channels in fear of losing control over intellectual property.

Universities most often participate in research projects that are several years away from commercialization. This may be reflected in the mixed regression results across many of the commercialization variables examined in this study.

\section{Additional studies of ATP research alliances}

In a study by Sakakibara and Branstetter, it was found that there existed ".... positive association between the intensity of participation in research consortia and the overall research productivity of participants." The study also found "...the relationship between participation and research productivity to be positive, statistically significant, and robust..." When answering the question of what type of firm receives the largest benefits from participation in ATP-funded research consortia the study concludes "... larger firms with higher R\&D budgets (i.e., technologically more progressive firms) tend to benefit more from participation than other firms" (p. 2 in Sakakibara and Branstetter, 2002).

The study by Sakakibara and Branstetter was not specifically focused on small business participation. The study notes, "In the absence of panel data on the research inputs and outputs of smaller firms, it is difficult, however, to come to any definitive conclusions about the effect of size or overall R\&D spending on research outcomes." (p. 5 in Sakakibara and Branstetter, 2002)

Where the use of trade secrets has increased to protect commercial interests, research alliances may not present the best organizational structure for small businesses. ${ }^{\circ}$ Small businesses engaged in high-risk technology R\&D often possess only intellectual property at the end of a project. Dissemination of the knowledge through patents and publications, while helpful in creating social benefits, may not always be advantageous to the survival of a company.

In a study utilizing a survey of ATP-funded companies, the question of whether projects with university participation were more likely to accelerate and commercialize sooner than those without university participation concluded "...that university participation seemed to have no impact on the generation of new applications." (p. 7 in Hall et al. 2002) Another conclusion stated that "Projects involving universities are less likely to develop and commercialize technology sooner than expected." (p. 22 in Hall et al. 2002) Similar results were found in this study.

Membership in research alliances has much to offer; small businesses but small businesses should (and often do) enter into research alliances with the knowledge that their survival as a business is something that only they are concerned with and take the proper actions to secure this objective. The data used in this study include only the time period in which companies participated in the ATP. Due to the nature of the R\&D undertaken by these companies, project success may not occur until some time after ATP funding had ended. 


\section{Conclusions}

The intent of this study was to examine the hypothesis that small businesses participating in the ATP would be more successful in technology R\&D both in terms of technical and commercial success if they are a member of a research alliance. The two types of research alliances examined in this study include membership in a joint venture and a single applicant with subcontractor(s). The findings add to our knowledge of the complexity of experience of small businesses participating in joint ventures.

A second hypothesis examined the type of organizational structure chosen by small businesses to accomplish their project objectives. The story that emerges is that participation as a member of a joint venture resulted in negative and statistically significant outcomes. Single applicants with subcontractor(s) recorded positive and significant results in terms of the indicators towards technical and commercial progress. The results are similar (with more positive signs) for a small business participating in a joint venture when they assume the role of the joint venture lead. This is consistent with previous research done on ATP awardees. Joint venture membership (non-lead) often brings important technical skills to projects, but it is the lead organization that generally holds the IP and exercises leadership in commercialization.

Using data on small businesses participating in the ATP, it can be determined that mere membership in a research alliance does not necessarily offer a panacea; rather, it is the position of the small business within the organizational structure of the research alliance that matters. Regular membership in a research alliance resulted in negative and statistically significant outcomes while participation as the joint venture lead resulted in positive and statistically significant outcomes. Alliances formed with subcontractor(s) offered mostly positive results.

It is common for small business participants in research alliances to undertake one task or develop one piece of the technology. Upon project completion, individual members either pursue commercialization on their own or surrender ownership to the other members of the alliance. Serving as the joint venture lead does contribute to a degree of commercial success as the small business is in more of a position of control regarding the outcome of the $R \& D$ project.

The contributions by research alliances to small businesses undertaking high-risk technology research and development have been the focus of this study. The conclusions reached do not imply that ATP joint ventures led to less success in terms of technical and commercial achievements; rather, small businesses engaged in ATP joint ventures as regular members did not benefit as much as small businesses participating as a single applicant or those assuming the role of the joint venture lead. Other observations include the following:

- This study may be just a small business story. ATP-funded joint ventures have resulted in significant technical and commercial successes as described in three reports examining, in detail, the results of the completed projects (Advanced Technology Program 2001, 2006a, 2006b).

- The conclusions are not saying that ATP-funded joint ventures led to less patenting; rather, ATP joint venture participants (especially small companies) did not patent as much as small company single applicants during the active project period. 
- The lack of statistical significance for the publications/presentations variables could be attributed to the desire to patent before publishing, the emergence of trade secrets as an industry norm, the importance of attracting additional funding, and the necessity of getting a product to market.

- The lack of statistical significance and the presence of negative signs for many of the variable estimates examined when a university participated in a research alliance may be attributed to the manner by which small businesses view and interact with universities. For the types of technology R\&D undertaken in an ATP project small companies may have partnered with universities to access their resources and services. Many small businesses may experience a degree of apprehension when working with academic institutions which are more concerned about publications than about proprietary information.

The apparent negative outcomes experienced by small businesses which are members of - but do not lead - joint ventures may only be telling a portion of the story. This finding raises the question of why these small businesses participate in joint ventures if they do not experience positive outcomes. Some possible explanations may be the following:

There is a difference between ex ante expectations and ex post results - i.e., their preproject expectations do not materialize.

Perhaps they are in fact experiencing positive results that are not being captured in these statistics (the value associated with formation of long-term partnerships and collaboration, for example), or possibly, they will see positive results in the future.

\section{Endnotes}

${ }^{a}$ Small businesses are defined as having fewer than 500 employees.

${ }^{\mathrm{b}}$ The Advanced Technology Program was located at the National Institute of Standards and Technology, US Department of Commerce, Gaithersburg, MD (ATP (2011). What's new in ATP? www.atp.nist.gov). On August 9, 2007, the President signed the America COMPETES Act (H.R. 2272) which abolished the Advanced Technology Program and created the Technology Innovation Program (TIP). TIP is responsible for the continued management of ATP projects.

${ }^{\mathrm{c}}$ This analysis does not include the awards made from the 2007 competition.

${ }^{\mathrm{d}}$ The ATP tracked technical milestones for every project participant using its BRS, which compiled data annually during the project period and every 2 years for 6 years following the project's end date. (Advanced Technology Program (2005). Evaluation Best Practices and Results: The Advanced Technology Program. NISTIR 05-7174. $<$ http://www.atp.nist.gov/eao/ir05-7174/chapt4.htm>).

'The ATP mission of 'accelerating the development of innovative technologies for broad national benefit through partnerships with the private sector' is obtained through achieving both.

${ }^{f}$ In any alliance with a subcontractor, it can be assumed that they do not have direct access to the same amount of knowledge as the co-signatories. Indirectly, however, they could. (Gulati et al. 2000), Gowrisankaran and Stavins (2002).

${ }^{\mathrm{g}}$ In the ATP, universities were not permitted to act as the lead in a research alliance; they were not permitted to hold intellectual property that resulted from a project without a negotiated agreement of the business participants. 
${ }^{\mathrm{h}}$ The CPRS assigns 0 to 4 stars to each completed project based on overall performance across multiple program objectives to show overall progress in three dimensions: (1) adding to the nation's scientific and technical knowledge base, (2) disseminating the knowledge, and (3) commercializing new and improved products and processes from the technology developed.

${ }^{\text {iS }}$ ubcontractors are not signatories to the ATP award.

'Interpretation of the regression results were conducted in conjunction with a series of interviews with ATP program managers.

${ }^{\mathrm{k}}$ The Manufacturing variable was omitted from the logistic analysis.

${ }^{\mathrm{I}}$ These insights were collected during a conversation with ATP project managers.

${ }^{m}$ Another study suggests losses of proprietary information and intellectual property by U.S. companies in the range of $\$ 53$ billion to $\$ 59$ billion annually. (p. 5 in ASIS International 2002)

${ }^{\mathrm{n}}$ Interpretation of the regression results was conducted through a series of interviews with ATP program managers

'In the 'New Economy' of the 21st century, a crucial responsibility of executives is the effective strategic management of intellectual property (IP). An emphasis on innovation and technology as a strategic driver of a firm's sustained competitive advantage has shifted the managerial focus to patents, copyrights, and trade secrets as methods of protecting intangible assets" (p. 479 in Hemphill 2004).

Competing interests

The authors did not provide this information.

Authors' information

RS is an economist at the National Institute of Standards and Technology. He was formerly employed in the ATP's Economic Assessment Office. Dr. RS, who received his Ph.D. in Economics from the University of Connecticut, has conducted research into the ATP's long-term impacts on the US economy and served as both the business chair and a project manager in the Information Infrastructure for Healthcare focused program.

\section{Acknowledgments}

The following ATP program managers offered invaluable insight into the interpretation of the regression results: Richard Bartholomew, Mrunal Chapekar, Barbara Cuthill, Andrew Klein, Bettijoyce Lide, Linda Schilling, and Jean Louis Staudenmann. I wish to thank the following people for their help in preparing this paper: for econometric assistance Ted Allen, Stephen Campbell, and Robert Sienkiewicz and for data assistance, Holly Jackson and Cindy McKneely.

Received: 14 February 2013 Accepted: 7 May 2013

Published: 20 December 2013

\section{References}

ACE. (2001). Working together, creating knowledge: the university-industry research collaboration initiative (pp. 3-11). Washington DC: ACE Fulfillment Service. http://www.acenet.edu/bookstore/pdf/working-together.pdf.

Acs, ZJ, \& Audretsch, DB (1987). Innovation, market structure, and firm size. The Review of Economics and Statistics, LXIX, 4.

Advanced Technology Program. (2001). Performance of 50 Completed ATP Projects. Status Report Number 2: NIST Special Publication 950-2 NIST. Washington, DC: U.S. Government Printing Office. http://www.atp.nist.gov/eao/sp950-2/ contents.htm.

Advanced Technology Program. (2005). Proposal Preparation Kit. http://www.atp.nist.gov.

Advanced Technology Program. (2006a). Performance of Second 50 Completed ATP Projects (Status Report Number 3: NIST Special Publication 950-3 NIST). Washington, DC: U.S. Government Printing Office. http://www.atp.nist.gov/ eao/sp950-3/contents.htm.

Advanced Technology Program. (2006b). Performance of the Third 50 Completed ATP Projects (Status Report Number 4 : NIST Special Publication NIST). Washington, D.C: U.S. Government Printing Office. http://www.atp.nist.gov/eao/ eao pubs.htm.

Advanced Technology Program. (various years). Proposal Preparation Kit.

Anderson, E. (1990). Two firms, one frontier: on assessing joint venture performance. Sloan Management Review, 31(2), 19-30

Anderson, G. (2004). The role of small firms in the US R\&D and innovation system: evidence from the advanced technology program. Presented at the American Statistical Association Meetings. Toronto: Canada.

ASIS International. (2002). Trends in proprietary information loss: survey report. PricewaterhouseCoopers, U.S.Chamber of Commerce, and ASIS Foundation. 
Audretsch, DB, \& Feldman, MP. (2003). Small-firm strategic research partnerships: the case of biotechnology. Technology Analysis \& Strategic Management, 15(2), 273-288.

Baumol, WJ (2004). Education for innovation: entrepreneurial breakthroughs vs corporate incremental improvements. Cambridge: NBER. NBER Working Paper Series, \#10578.

Branscomb, LM, \& Auerswald, PE (2002). Between invention and innovation: an analysis of funding for early-stage technology development. U.S. Department of Commerce. NIST GCR 02-841. Gaithersburg: National Institute of Standards and Technology.

Caloghirou, Y, loannides, S, \& Vonortas, NS. (2003). Research joint ventures: acritical survey of theoretical and empirical literature. Journal of Economic Surveys, 17(4), 541-570.

Dyer, JH, Powell, BC, Sakakibara, M, \& Wang, AJ (2006). Determinants of Success in R\&D Alliances. NISTIR 7323. Gaithersburg: National Institute of Standards and Technology.

Gowrisankaran, G, \& Stavins, J (2002). Network Externalities and Technology Adoption: Lessons from Electronic Payments. NBER Working Paper \# 8943. Cambridge: NBER.

Gulati, R, Nohire, N, \& Zaheer, A (2000). Strategic networks. Strategic Management Journal, 21(Special Issue-Strategic Networks), 203-215.

Hagedoorn, J, Link, AN, \& Vonortas, NS. (2000). Research partnerships. Research Policy, 29(4-5), 567-586.

Hall, BH, Link, AN, \& Scott, JT (2002). Universities as research partners. U.S. Department of Commerce, Advanced Technology Program. NIST GCR 02-829. Gaithersburg: National Institute of Standards and Technology.

Hemphill, TA. (2004). The strategic management of trade secrets in technology-based firms. Technology Analysis \& Strategic Management, 16(4), 479-494.

Jaffe, A (1996). Economic analysis of research spillovers: implications for the advanced technology program. U.S. Department of Commerce, NIST GCR 97-708. Gaithersburg: National Institute of Standards and Technology.

Litvak, I (1992). Public policy and high technology SMES: the government embrace. Canadian Public Administration, 35, 1.

Miles, G, \& Preece, SB (1995). Public promotion of new technology ventures: an agency perspective. Canadian Public Administration, 38, 3 .

Miles, G, Preece, SB, \& Baetz, MC. (1999). Dangers of dependence: the impact of strategic alliance use by small technology-based firms. Journal of Small Business Management, 37, 2.

Nicholls-Nixon, CL, \& Woo, CY. (2003). Technology sourcing and output of established firms in a regime of encompassing technological change. Strategic Management Journal, 24, 651-666.

Powell, J (1996). The ATP's Business Reporting System: A Tool for Economic Evaluation. In Proceedings, Conference on Competitive Analysis of Enterprise Data. Helsinki, Finland. Gaithersburg: National Institute of Standards and Technology.

Powell, J, \& Morris, F (2002). Different Timelines for Different Technologies: Evidence from the Advanced Technology Program. U.S. Department of Commerce Advanced Technology Program. NISTIR 6917. Gaithersburg: National Institute of Standards and Technology.

Rothwell, R. (1983). Innovation and firm size: a case for dynamic complementarity; or, is small really so beautiful? Journal of General Management, 8(3), 5-25.

Ruegg, R (2006). Bridging from Project Case Study to Portfolio Analysis in a Public R\&D Program: A Framework for Evaluation and Introduction to a Composite Performance Rating System. U.S. Department of Commerce Advanced Technology Program. NIST GCR 06-891. Gaithersburg: National Institute of Standards and Technology.

Sakakibara, M, \& Branstetter, L (2002). Measuring the Impact of ATP-Funded Research Consortia on Research Productivity of Participating Firms: A Framework Using Both U.S. and Japanese Data. U.S. Department of Commerce Advanced Technology Program. NIST GCR 02-830. Gaithersburg: National Institute of Standards and Technology.

Sorenson, O, \& Fleming, L. (2004). Science and the diffusion of knowledge. Research Policy, 33(10), 1615-1634.

Vonortas, NS (1997). Cooperation in research and development. Boston, MA; Dordrecht, Netherlands: Kluwer Academic Publishers.

Vonortas, NS, \& Richard, N (2005). Spivack "Advanced Technology Program Information Infrastructure for Healthcare: Case Studies from a Focused Program" Working Paper. Advanced Technology Program: Economic Assessment Office. Gaithersburg: National Institute of Standards and Technology.

doi:10.1186/2192-5372-2-19

Cite this article as: Spivack: Small business participation in the advanced technology program research alliances. Journal of Innovation and Entrepreneurship 2013 2:19.

\section{Submit your manuscript to a SpringerOpen ${ }^{\circ}$} journal and benefit from:

- Convenient online submission

Rigorous peer review

- Immediate publication on acceptance

- Open access: articles freely available online

- High visibility within the field

- Retaining the copyright to your article

Submit your next manuscript at $\boldsymbol{\sim}$ springeropen.com 